\title{
Interactive effects between supplemental ultraviolet-B radiation and heavy metals on the growth and biochemical characteristics of Spinacia oleracea $\mathrm{L}$.
}

\author{
Shweta Mishra ${ }^{1}$ and S.B. Agrawal ${ }^{2 *}$
}

${ }^{1}$ Laboratory of Air Pollution and Global Climatic Change, Department of Botany, Allahabad Agricultural Institute-Deemed University, Allahabad- 211 007, India; ${ }^{2}$ Department of Botany, Banaras Hindu University, Varanasi-221 005, India; *Corresponding author: sbagrawal56@yahoo.com /sbagrawal@sify.com

Recived: 04/03/2006, Accepted: 01/06/2006

The impact of supplemental UV-B (sUV-B) radiation and heavy metals: Cd (68 $\mu$ mol. $\mathrm{kg}^{-1}$ soil) and Ni (68 $\mu \mathrm{mol} . \mathrm{kg}^{-1}$ soil) singly and in combination was studied on photosynthetic and non-photosynthetic pigments, metabolites, enzyme activities, biomass accumulation and the net primary productivity of spinach (Spinacia oleracea L. var. All Green), a common leafy vegetable plant. Both the stresses individually and in combination resulted in the reduction of photosynthetic pigments, ascorbic acid, and catalase activity, whereas a reverse trend was observed for anthocyanin, flavonoids and proline content, lipid peroxidation and peroxidase activity. The interactive effects of both the stresses were, however, less than additive. Combined treatment of sUV-B + Cd was more deleterious as compared to sUV-B $+\mathrm{Ni}$ and other individual treatments.

Key words: Spinaicia oleracea, biomass, cadmium, enzymes, nickel, pigments, ultraviolet-B.

Efeitos interativos entre radiação ultravioleta B suplementar e metais pesados no crescimento e características bioquímicas de Spinacia oleracea L.: Estudou-se o impacto de radiação UV-B suplementar (sUV-B) e dos metais pesados Cd (68 $\mu$ mol. $\mathrm{kg}^{-1}$ solo) e Ni (68 $\mu$ mol. $\mathrm{kg}^{-1}$ solo), isoladamente ou em combinação, sobre pigmentos fotossintéticos e não fotossintéticos, metabólitos, atividades enzimáticas, acúmulo de biomassa e produtividade primária de espinafre (Spinacia oleracea L. var. All Green). Ambos estresses, individualmente ou em combinação, resultaram na redução dos pigmentos fotossintéticos, ácido ascórbico, e atividade de catalase, sendo que uma tendência oposta foi observada para o conteúdo de antocianina, flavonóides e prolina, peroxidação lipídica e atividade de peroxidase. Os efeitos interativos de ambos estresses foram, no entanto, menos que se fossem aditivos. O tratamento combinado de sUV-B $+\mathrm{Cd}$ foi o mais deletério quando comparado com sUV-B $+\mathrm{Ni}$ e outros tratamentos individuais.

Palavras-chave: Spinaicia oleracea, biomassa, cádmio, enzimas, níquel, pigmentos, ultravioleta-B.

\section{INTRODUCTION}

A decrease in the concentration of stratospheric ozone is enhancing the solar ultraviolet-B (UV-B, 280-320 nm) radiation on the earth's surface (Caldwell et al., 1998). Several studies have indicated that supplemental UV-B radiation (sUV-B) can deleteriously affect physiological processes and overall growth in a number of plant species (Tevini, 2000; Rathore et al., 2003). Recently, Agrawal et al. (2004) reported the unfavorable effects of sUV-B on several physiological and biochemical processes in two cultivars of Triticum aestivum L. leading to reduction in biomass and grain yield

In recent years, besides increments in UV-B radiation, a great deal of interest has been generated on studies related to the toxic effects of heavy metals on plants. Heavy metal pollution is increasing in the environment due to mining, industrialization and other anthropogenic activities. Airborne heavy metals fall upon, react with, and are absorbed by plants 
and soils near the sites of pollutant generation. A characteristic feature of toxicities due to heavy metal is chlorosis and reduction in the net photosynthetic rate leading to decreased growth and productivity (Burton et al., 1986). Among heavy metal pollutants, nickel $(\mathrm{Ni})$ and cadmium $(\mathrm{Cd})$ need special attention due to their widespread occurrence and potential for their toxicities. $\mathrm{Cd}$ in higher concentration has been shown to disturb chlorophyll synthesis (Stobart et al., 1985) and many metabolic processes like nucleic acid and protein synthesis (Bingham et al., 1976).

Synergistic action of UV-B radiation and Cd was reported by Shukla et al. (2002) on the growth of wheat seedlings. Prasad et al. (2004) reported changes due to UV-B and $\mathrm{Cd}$ alone and in combination on photosynthetic pigments, photosynthetic electron transport activity, enzymatic and non-enzymatic antioxidants and lipid peroxidation in a liverwort, Riccia sp.

$\mathrm{Ni}$ is considered as an essential micronutrient for plants, but is strongly phytotoxic at higher concentrations (Boominathan and Doran, 2002). Ni-induced deactivation of proteins including antioxidant enzymes, lipid peroxidation and membrane function have been reported in plants (Madhava Rao and Sresty, 2000).

In view of the above facts, an assessment of multiple stress effects is very important in obtaining a more meaningful and realistic view of the current changes in the environment. The present investigation was aimed to assess the interactive effects of two potential stress factors i.e. sUV-B radiation and heavy metals $(\mathrm{Cd} / \mathrm{Ni})$ applied individually and in combination on the growth and biochemical characteristics of spinach (Spinacia oleracea L. var All Green), a common leafy vegetable plant.

\section{MATERIAL AND METHODS}

The present experiment was performed from March to April, 2003 in the field of Allahabad Agriculture Institute, Allahabad, Uttar Pradesh (24047' N latitude and $81^{\circ} 19^{\prime} \mathrm{E}$ longitude, at an elevation of about $96 \mathrm{~m}$ above sea level) situated in the eastern Gangetic plains of India. Spinach (Spinacia oleracea var. All Green) plants were grown in a soil pot culture at the level of $68 \mu$ mol. $\mathrm{kg}^{-1}$ soil $\mathrm{Cd}$ as $\mathrm{CdSO}_{4}$ and $68 \mu$ mol. $\mathrm{kg}^{-1}$ soil $\mathrm{Ni}$ as $\mathrm{NiCl}_{2}$ in 10 pots each. The concentrations of $\mathrm{Cd}$ and $\mathrm{Ni}$ selected for experiment fall within Indian standards for heavy metals in soil (Awasthi, 2000). The pots were uniformly watered throughout the experiment in order to maintain constant soil moisture. Ten pots without heavy metal amendment were kept as a control. Five pots of each treatment $(\mathrm{Cd}, \mathrm{Ni}$, and control) were randomly selected for sUV-B exposure.

Supplemental UV-B (sUV-B) radiation was artificially provided by Q panel UV-313 fluorescent lamps (Q-panel, Cleveland, U. S. A.) suspended above and perpendicular to the pots. Cellulose diacetate and polyester films were used to transmit sUV-B (cutoff ca. $292 \mathrm{~nm}$ ) and exclude UV-B (cutoff ca. $318 \mathrm{~nm}$ ). The control plants thus received only ambient levels of UV-B. Plants one week after emergence were exposed to radiation for $3 \mathrm{hr}$ day $^{-1}$ (9:30 a.m. to 12:30 p.m.) for 45 days. The UV-B radiation at the top of the plant canopy was measured by an Ultraviolet Intensity Meter (UVP Inc., San Gabriel, CA, USA). The readings were converted to $\mathrm{UV}-\mathrm{B}_{\mathrm{BE}}$ values by comparing $\mathrm{UV}$ meter readings with a Spectro Power Meter (Scientech Inc, Boulder, CO, USA). Plants under polyester filter lamps received $8.6 \mathrm{KJ} . \mathrm{m}^{-2} \mathrm{UV}$ $\mathrm{B}_{\mathrm{BE}}$ on the summer solstice, measured against the generalized plant response action spectrum of Caldwell (1971). The plants beneath the cellulose diacetate film received ambient $\left(8.6 \mathrm{KJ} \cdot \mathrm{m}^{-2}\right)+7.1 \mathrm{KJ} \cdot \mathrm{m}^{-2} \mathrm{UV}-\mathrm{B}_{\mathrm{BE}}$ that mimicked the $20 \%$ reduction in the stratospheric ozone at Allahabad (20047' $\mathrm{N})$ during clear sky conditions during the summer solstice normalized at $300 \mathrm{~nm}$. The ozone column thickness was assumed to be $3.0 \mathrm{~mm}$, the albedo 0 and the scatter 1.0. Three plants were sampled randomly from three replicate pots of each treatment at 15, 30 and 45 days after sowing (DAS) for determination of the various parameters.

During the study period the mean minimum and mean maximum temperatures ranged between 14.9 to $24.3^{\circ} \mathrm{C}$ and 30.8 to $34.6^{\circ} \mathrm{C}$, respectively. The average relative humidity varied between 59.8 and $68.4 \%$ and PAR ranged between 1,100 to $1,200 \mu \mathrm{mol} \cdot \mathrm{m}^{-2} \cdot \mathrm{s}^{-1}$. There were negligible differences between temperature, relative humidity and PAR under sUV-B exposed plants and other treatments.

For all biochemical analyses leaf samples were taken at 9 a.m. and kept in a deep freezer for further analysis. There was no significant difference in the fresh/dry weight ratio of sampled tissues. Estimation of chlorophyll, carotenoids, anthocyanin and flavonoid contents was done by the methods described by Rathore et al. (2003). Leaf samples were homogenized in oxalic acid and NaEDTA extraction solution for ascorbic acid content determination as described by Keller and Schwager (1977). Determination of proline was performed by the ninhydrin assay using the method of Plummer (1979). Lipid peroxidation in the leaf tissue was measured in terms of malondialdehyde (MDA, a product of 
lipid peroxidation) content by the thiobarbituric acid (TBA) reaction as described by Heath and Packer (1968). Catalase and peroxidase activities were measured by the methods described by Agrawal et al. (2004).

For total biomass, randomly sampled plants were dried at $80^{\circ} \mathrm{C}$ until a constant weight was achieved.

To check the significant effects of the treatments and interactions between the treatments at different growth stages, statistical analysis was carried out using the SPSS software (SPSS Inc., version 7.0).

\section{RESULTS}

Total chlorophyll and carotenoid contents declined in all the treated plants at all ages as compared to the controls (figure 1). However, per cent reductions decreased with the increase of plant age. Maximum reductions of $25.4 \%$ in chlorophyll and $27.4 \%$ in carotenoid contents were observed in sUV-B $+\mathrm{Cd}$ treated plants at 15 DAS, as compared to the controls. A three way analysis of variance showed significant variations in the above parameters due to all the factors and their interactions (table 1). Anthocyanin and flavonoid contents did not change significantly in response to individual treatments of $\mathrm{Cd}$ or Ni. However, they showed a marked increase in plants treated with sUV-B alone and in combination with either metal $(\mathrm{Cd} / \mathrm{Ni})$. The maximum increments of 66.6 and $72.6 \%$ in anthocyanin and flavonoid contents, respectively were observed at 45 DAS in sUVB treated plants without application of any heavy metal (figure 1). Multivariate analysis of the variance test showed significant variations in anthocyanin and flavonoid contents due to sUV-B treatment, plant age, age $\times$ treatment, and sUV-B treatment $\times \mathrm{Cd} / \mathrm{Ni}$ interactions (table 1). Catalase activity decreased with treatment of by sUV-B, Cd or $\mathrm{Ni}$ and combinations of sUV-B and metals in plants at all the ages. The percentage of reductions increased with increase in age, being most severe in the combined treatments of sUV-B + Cd (67.8 \%) and sUV-B + Ni (61.6\%), followed by the individual treatments sUV-B (54.8\%), Cd (32.8\%) and $\mathrm{Ni}(26.1 \%)$ at $45 \mathrm{DAS}$ (figure 2). In contrast to catalase, peroxidase activity increased in all the treatments at all ages. Peroxidase activity showed maximum increment under sUV$\mathrm{B}+\mathrm{Cd}(74.3 \%)$ combinations followed by sUV-B + Ni (70.9 $\%)$, sUV-B (70.3 \%), Cd (63.4\%) and Ni (50.9\%) (figure $2)$. A three way analysis of variance test showed significant variations in enzyme activities due to all the factors and their interactions (table 1).
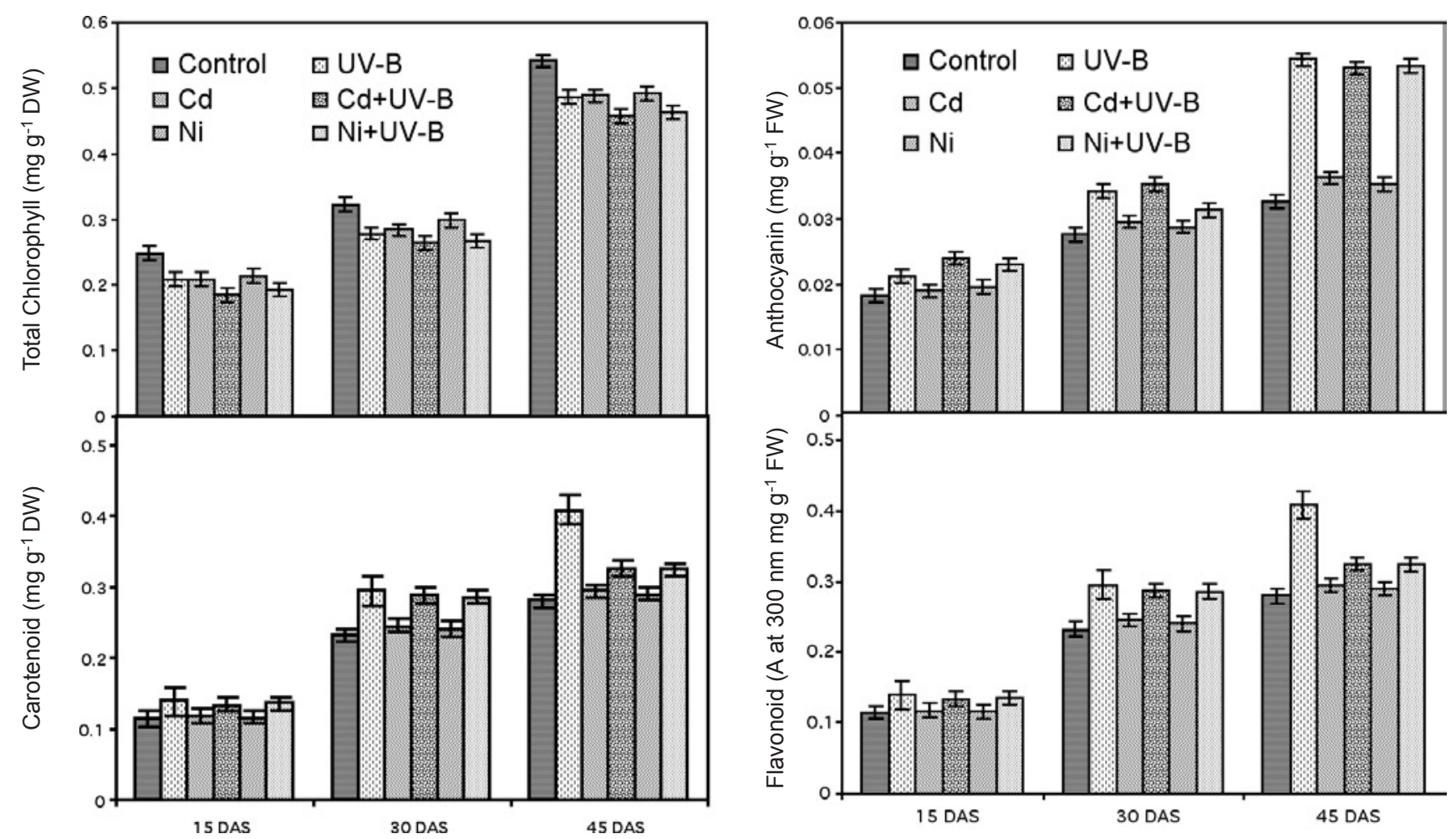

Figure 1. Effects of sUV-B radiation and heavy metal (Cd/ Ni) singly and in combination on photosynthetic and nonphotosynthetic pigments of Spinacia oleracea L. at 15, 30 and 45 DAS (mean \pm S.E.). 


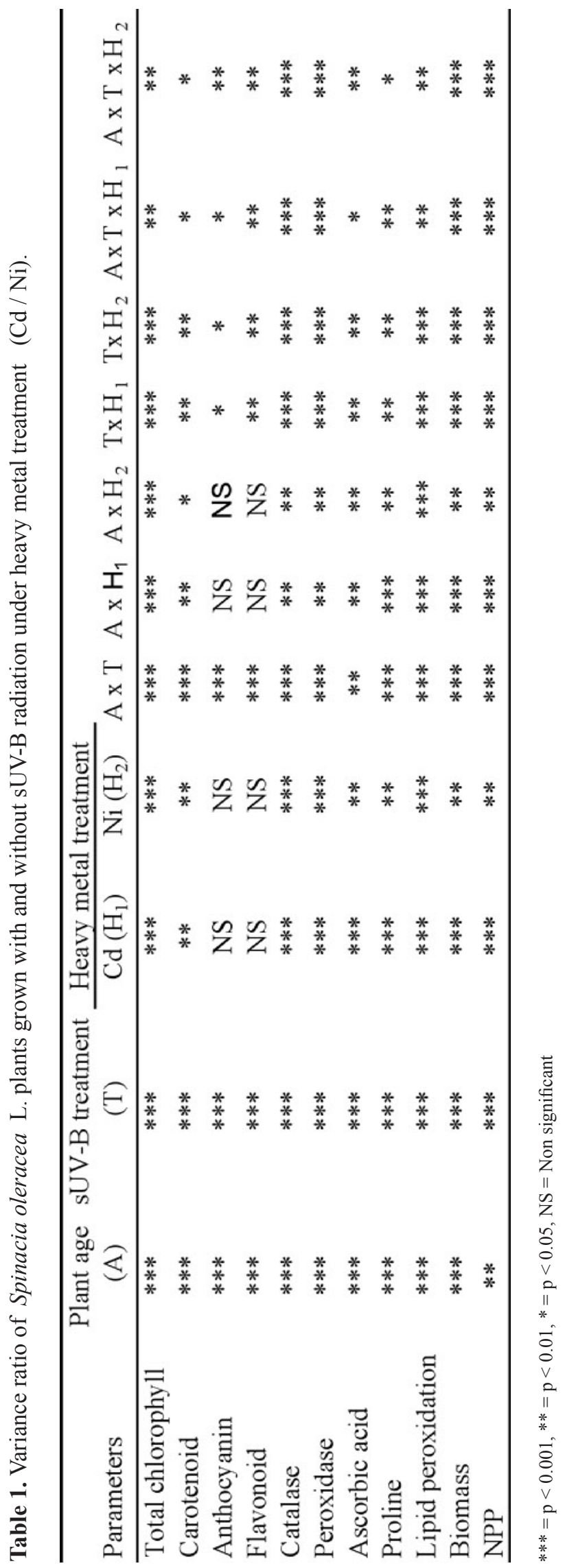

An increase in the level of lipid peroxidation was observed in all the treated plants at all the ages, being maximum with the sUV-B $+\mathrm{Cd}(29.6 \%)$ treatment followed by sUV-B + Ni (26.0 \%), sUV-B (24.2\%), Ni (13.7\%) and $\mathrm{Cd}(13.1 \%)$ at 45 DAS (figure 3). Variations in lipid peroxidation were significant due to all the factors and their interactions (table 1). Ascorbic acid content decreased due to various treatments, reduction being maximum (56.7\%) in plants treated with sUV-B $+\mathrm{Cd}$ at 15 DAS (figure 2). A three-way analysis of variance showed significant variations in ascorbic acid and proline contents due to plant age, sUV-B, and heavy metal treatments as well as their interactions (table 1). There was a sharp increase in proline accumulation due to different treatments at all the ages of observations (figure 2). However, combined treatments of both the stresses showed higher accumulation (47.5 and $42.9 \%$ for sUV-B+ $\mathrm{Cd}$ and $\mathrm{sUV}-\mathrm{B}+\mathrm{Ni}$, respectively) than individual treatments of sUV$\mathrm{B}(38.2 \%), \mathrm{Cd}(27.7 \%)$ and $\mathrm{Ni}(26.2 \%)$ at $15 \mathrm{DAS}$.

The total plant biomass decreased significantly in all the treated plants at all the sampling stages (figure 4). Reductions of $16.7 \%, 18.6 \%$ and $18.5 \%$ were observed at 45 DAS with the sUV-B, $\mathrm{Cd}$ and Ni treatments. Maximum reductions were observed in combined treatments of sUV-B $+\mathrm{Cd}$ and sUV$\mathrm{B}+\mathrm{Ni}$, the reductions being $25.3 \%$ and $24.1 \%$, respectively at $45 \mathrm{DAS}$ as compared to the controls (without sUV-B/heavy metal treatment). The interactive effects of the stresses were always less than additive. Net primary productivity (NPP) showed a similar pattern as that of biomass (figure 4). A multivariate analysis of variance showed significant effects of all the factors and their interactions on biomass and NPP (table 1).

\section{DISCUSSION}

Chlorophyll and carotenoids are the central part of the energy manifestation of every green plant system and therefore, any significant alteration in their levels is likely to cause a marked effect on the entire metabolism of the plants. In the present experiment, both sUV-B and heavy metal $(\mathrm{Cd} / \mathrm{Ni})$ exposure decreased the chlorophyll and carotenoid contents of the test plant. Reduction in chlorophyll contents by excess $\mathrm{Ni}$ and $\mathrm{Cd}$ has been reported in the pigeon pea (Sheoran et al., 1990) and spinach (Dube et al., 2002). High $\mathrm{Cd}$ inhibits the formation of chlorophyll by interfering with protochlorophyllide production (Stobart et al., 1985). A 30 $\%$ reduction in the total chlorophyll of pea leaves exposed to UV-B has been reported by Day and Vogelmann (1995). A decrease of chlorophyll content by $7 \%$ as compared to 

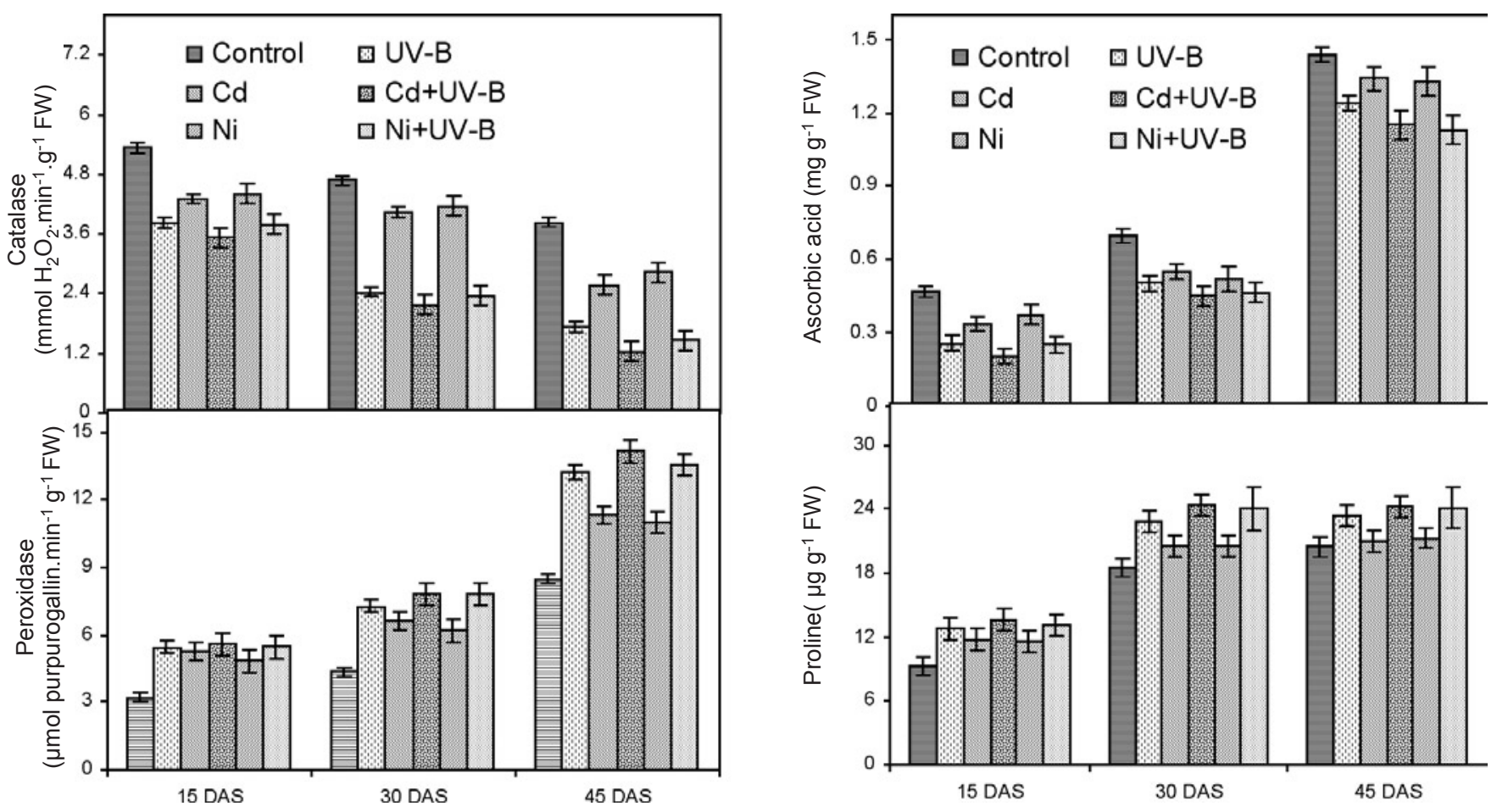

Figure 2. Effects of sUV-B radiation and heavy metal $(\mathrm{Cd} / \mathrm{Ni})$ singly and in combination on catalase and peroxidase activiy, ascorbic acid and proline contents of Spinacia oleracea L. at 15, 30 and 45 DAS (mean \pm S.E.).

the control was reported in Brassica campestris L. plants after exposure to UV-B and Cd (Bornman and Dube, 1991). Several other reports have also suggested a reduction in carotenoid following sUV-B exposure (Tevini et al., 1981, Premkumar and Kulandaivelu, 1996). Carotenoids protect chlorophyll from photooxidative destruction (Middleton and Teramura, 1993) and therefore, a reduction in carotenoid could have a serious consequence on chlorophyll pigments. Prasad et al. (2004) noticed reductions of $18 \%, 47 \%$ and 58 $\%$ in chlorophyll content with UV-B, $1000 \mu \mathrm{mol} \mathrm{Cd}$ and UV$\mathrm{B}+\mathrm{Cd}$, respectively.

The accumulation of UV-B absorbing pigments is one of the ways by which plants alleviate the harmful effects of UVB. In the present study, anthocyanin content increased after sUV-B treatment, but not significantly after treatment with heavy metals. An increase in anthocyanin content due to UVB exposure has also been reported in Vigna mungo (Britto and DeBritto, 1995). Flavonoids showed a higher value in sUV-B and sUV-B + heavy metal $(\mathrm{Cd} / \mathrm{Ni})$ treated plants as compared to individual treatment with heavy metals or control plants. Increase in flavonoid content is in support of the results obtained by Rathore et al. (2003) in two cultivars of Triticum aestivum $\mathrm{L}$.
Decline of catalase activity and increase in peroxidase activity was also reported by Rathore et al. (2003) in Triticum aestivum L. under SUV-B radiation and by Panda and Khan (2003) and Shah et al. (2001) in Oryza sativa plants under heavy metal toxicity. Catalase and peroxidase are important in the antioxidant defense system for scavenging $\mathrm{H}_{2} \mathrm{O}_{2}$ and free radicals (Bowler et al., 1992). Antioxidants catalase, peroxidase and carotenoids are effective quenchers of reactive oxygen species (ROS) and play an important role in adaptation and ultimate survival of plants during periods of stress. Decreased levels of catalase and carotenoids and increased levels of peroxidase induced by oxidative stress, reflected a general strategy required to overcome the stress and protect cells against damage.

Ascorbate is a major antioxidant and its reduction suggested its reaction directly with ROS generated by sUV$\mathrm{B}, \mathrm{Cd}, \mathrm{Ni}$ and their combinations and also its utilization in reducing the oxidized form of $\alpha$-tocopherol. Ascorbic acid acts as an in vitro biological antioxidant, and functions as a co-substrate of plant peroxidases (Halliwell, 1982). Singh (1996) also reported significant reductions in the ascorbic acid content of three leguminous plants (Vigna radiata L., Phaseolus mungo L., and Glycine max L.) after exposure to enhanced UV-B radiation. 
Proline, an osmoprotectant, accumulated under all treatments i.e. sUV-B, Cd, Ni, and their combinations. Heavy metals and sUV-B exposure give raise to a series of reactions which generate numerous free radicals which may be reflected by altered levels of major anions and accumulation of proline

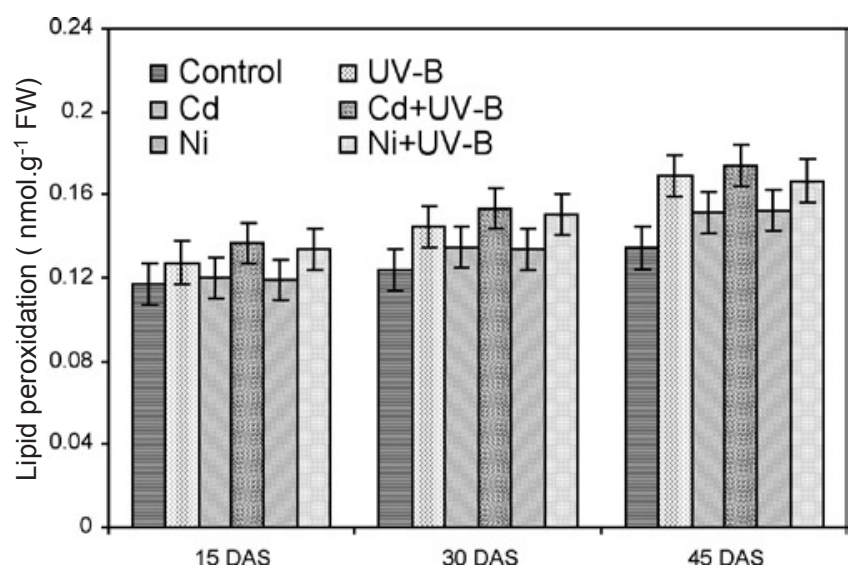

Figure 3. Effects of sUV-B radiation and heavy metal $(\mathrm{Cd} /$ $\mathrm{Ni}$ ) singly and in combination on lipid peroxidation (MDA concentration) of Spinacia oleracea L. at 15, 30 and 45 DAS (mean \pm S.E.).

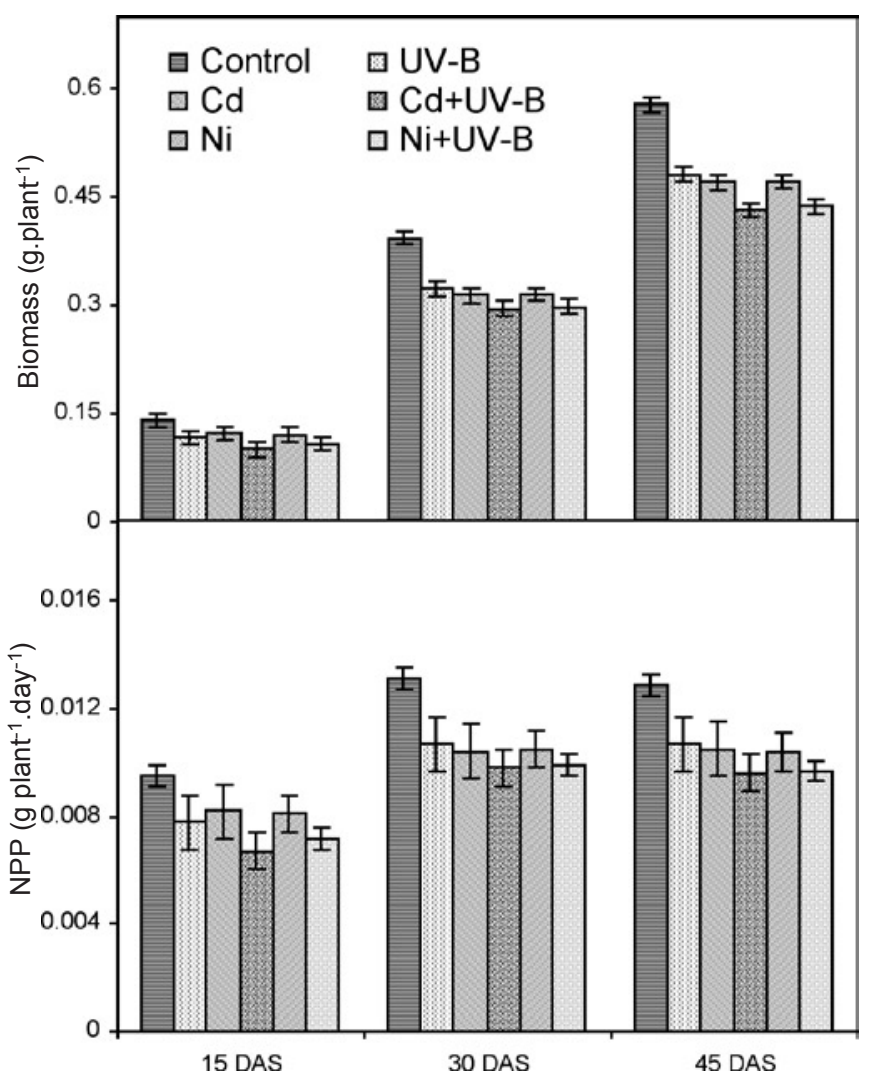

Figure 4. Effects of sUV-B radiation and heavy metal $(\mathrm{Cd} /$ $\mathrm{Ni}$ ) singly and in combination on biomass and net primary productivity of Spinacia oleracea L. at 15, 30 and 45 DAS (mean \pm S.E.).
(Alia and Pardha Saradhi, 1991). Proline is supposed to participate in the reconstruction of chlorophyll, activates the Krebs cycle and constitutes an energy source (Saxe, 1991). It is also an important part of structural proteins and enzymes and participates in repair processes. Recently, Chris et al. (2006) have shown that simultaneous exposure of sUV-B and $\mathrm{NaCl}$ produced an additive effect on MDA and proline accumulation in a cyanobacterium Cylindrospermum sp.

In the present study, LPO increased due to various treatments at all ages. A combination of sUV-B and heavy metal $(\mathrm{Cd} / \mathrm{Ni})$ produced more $\mathrm{LPO}$ as compared to individual treatments of either stress. The effect of UV-B on the membrane is related to the oxidation of the membrane components by free radicals (Predieri et al., 1995). Similar responses were observed in crop plants for various heavy metals (Somashekaraiah et al., 1992). Ni produced a constant increase in MDA concentration (about $47 \%$ ) in Nicotiana tabacum (Boominathan and Doran, 2002). Studies of Shah et al. (2001) suggested that rice plants freely absorbed $\mathrm{Cd}$ and its accumulation in tissues was paralleled with enhanced lipid peroxidation and marked elevation in the levels of antioxidant enzymes. Lipid peroxidation also increased in Riccia sp. thalli with rising concentration of $\mathrm{Cd}$ and $\mathrm{UV}-\mathrm{B}$ exposure alone and also in combined treatments of Cd and UV-B.

Reduction in biomass accumulation is often a reliable indication of the plant's sensitivity to various stresses, as it represents the cumulative effects of damaged or inhibited physiological functions. The exposure to sUV-B and heavy metal stress caused significant reductions in biomass accumulation and NPP. Similar reductions in the biomass yield were observed by Shukla et al. (2002) in Triticum aestivum (wheat) seedlings due to the combined stress of UV-B and Cd. Haghiri (1973) also reported a sharp decline in the yield of dry matter in soybean and wheat at the lowest level of applied $\mathrm{Cd}$ (2-5 ppm). Dube et al. (2002) noticed reductions of 10.8, 20, 38.4 and $72.4 \%$ in spinach biomass with the application of 5 , 10, 20 and $40 \mathrm{mg} \mathrm{Cd} . \mathrm{kg}^{-1}$ soil, respectively.

Concluding, the present investigation showed that sUV-B and heavy metal treatments caused oxidative stress in plants leading to reductions in photosynthetic pigments and consequently the biomass of spinach plants. Proline accumulation appears to be an additional defense against UV-B and metal-induced oxidative stress. The combined effects of sUV-B and Cd caused the strongest reduction in biomass at final harvest followed by the treatments sUV-B $+\mathrm{Ni}, \mathrm{Cd}, \mathrm{Ni}$ and sUV-B. Interactive effects of sUV-B $+\mathrm{Cd} /$ sUV-B $+\mathrm{Ni}$, however, were always less than additive. This 
study further concludes that an increasing availability of UV$\mathrm{B}$ in a natural system would intensify metal toxicity in the plants inhabiting metal rich environments.

Acknowledgements: The authors are thankful to C.S.I.R. (New Delhi) for financial assistance and to Prof. R.B. Lal, Vice Chancellor and Dr. G. Abraham, Head, Botany Department, Allahabad Agricultural Institute-DU, Allahabad for the necessary facilities and encouragements.

\section{REFERENCES}

Agrawal SB, Rathore D, Singh A (2004) Combined effects of enhanced UV-B radiation and additional nutrients on two cultivars of wheat (Triticum aestivum L.). Physiol. Mol. Biol. Plants. 10:99-108.

Alia, Pardha Saradhi P (1991) Proline accumulation under heavy metal stress. J. Plant Physiol. 138:554-558.

Awasthi SK (2000) Prevention and food adulteration Act $\mathrm{n}^{\circ}$ 37 of 1954. Central and State rules as amended for 1999. III rd Edition, Ashoka Law House, New Delhi.

Bingham FT, Page AL, Mahler RJ, Gange TJ (1976) Yield and cadmium accumulation of forage species in relation to cadmium content of sludge amended soil. J. Environ. Qual. 5:57-60.

Boominathan R, Doran PM (2002) Ni-induced oxidative stress in roots of Ni hyperaccumulator, Alyssum bertolonii. New Phytol. 156:205-215.

Bornman JF, Dube S (1991) The response of plants to ultraviolet-B radiation and metal stress. In: Abrol. YP, Wattal PN, Govindjee, Ort DR, Terramura AH (eds), Plant Impact of global climatic changes on photosynthesis and productivity, pp.125-132. Oxford \& IBH Publish. Co. Pvt. Ltd., New Delhi.

Bowler C, VanMoutage M, Inze D (1992) Superoxide dismutase and stress tolerance. Annu. Rev. Plant Physiol. Mol. Biol. 43:83-116.

Britto AJ de, De Britto AJ (1995) Influence of UV-B radiation on Phaseolus mungo. J. Ecotoxicol. Environ. Monitor. 5:113-117.

Burton KW, Morgan E, Rotg A (1986) Interactive effects of cadmium, copper and nickel on the growth of sitka spruce and studies of metal uptake from nutrient solutions, New Phytol. 103:519-557.

Caldwell MM (1971) Solar UV irradiation and the growth and development of higher plants In: Giese AC (ed.), Photophysiol. (vol.6):131-171.

Caldwell MM, Bjorn LO, Bornman JF, Flint SD, Kulandaivelu G, Teramura AH, Tevini, M (1998) Effects of increased solar ultraviolet radiation on terrestrial ecosystems. J. Photochem. Photobiol. B 46:40-52.

Chris A, Zeeshan M, Abraham G, Prasad SM (2006) Proline accumulation in Cylindrospermum sp. Environ. Exp. Bot. 57:154-159.

Day TA, Vogelmann TC (1995) Alteration in photosynthesis and pigment distribution in pea leaves following UV-B exposure. Physiol. Plant. 94:433-440.
Dube BK, Sinha P, Chatterjee C (2002) Changes in spinach metabolism by excess cadmium. Nature Environ. Pollut. Tech. 1:225-229.

Haghiri F (1973) Cadmium uptake by plants. J. Environ. Qual. 2:93-96.

Halliwell B (1982) Ascorbic acid and the illuminated chloroplast. In: Seib PA, Tolbert BW (eds.).Ascorbic acid: chemistry, metabolism and uses, pp.263-274. American Chemical Society, Washington.

Heath RL, Packer L (1968) Photoperoxidation in isolated chloroplast. I. Kinetics and stoichiometry of fatty acid peroxidation. Arch. Biochem. Biophys. 125:189-198.

Keller T., Schwager H S (1977) Air pollution and ascorbic acid. Europ. J. For. Pathol. 7:338-350.

Madhava Rao KV, Sresty TVS (2000) Antioxidative parameters in the seedlings of pigeonpea (Cajanus cajan (L.) Millspaugh) in response to Zn and Ni stresses. Plant Sci. 157:113-128.

Middleton EM, Teramura AH (1993) The role of flavonol glycosides and carotenoids in protecting soybean from UV-B damage. Plant Physiol. 103:741-752.

Panda SK, Khan MH (2003) Antioxidant efficiency in rice (Oryza sativa L.) leaves under heavy metal toxicity. J. Plant Biol. 30:23-29.

Plummer DT (1979) Introduction to Practical Biochemistry. Tata McGraw Hill Publishing Co. Ltd., U.K.

Prasad SM, Dwivedi R, Zeeshan M, Singh R (2004) UV-B and cadmium induced changes in pigments, photosynthetic electron transport activity, antioxidant levels and antioxidative enzyme activities of Riccia sp. Acta Physiol.Plant. 26:423-430.

Predieri S, Norman HA, Krizek DT, Pillai P, Mirecki RM, Zimmerman RH (1995) Influence of UV-B radiation on membrane lipid composition and ethylene evolution in 'Doyunene D' Hiver per shoot grown in in vitro under different photosynthetic photon fluxes. Environ. Exp. Bot. 35: 151-160.

Premkumar A, Kulandaivelu G (1996) Influence of UV-B enhanced solar radiation on growth and photosynthesis of potassium deficient cowpea seedlings. Photosynthetica 32:521-528.

Rathore D, Agrawal SB, Singh A (2003) Influence of supplemental UV-B radiation and mineral nutrients on biomass, pigments and yield of two cultivars of wheat (Triticum aestivum L.). Int. J. Biotronics 32:1-15.

Saxe H. (1991) Photosynthesis and stomatal response to polluted air and the use of physiological and biochemical responses easy detection and diagnostic tools. In: Gallow JA (ed.), Advances in Botanical Research, pp.1-128. Academic Press, Toronto.

Shah K, Kumar RG, Verma S, Dubey RS (2001) Effect of cadmium on lipid peroxidation, superoxide anion generation and activities of antioxidant enzymes in growing rice seedling. Plant Sci. 161:1135-1144.

Sheoran IS, Singhal HR, Singh R (1990) Effect of Cd and Ni on photosynthesis and the enzymes of the photosynthet- 
ic carbon reduction cycle in pigeonpea. Photosynth. Res. 23:345-351.

Shukla UC, Joshi PC, Kakkar P (2002) Synergistic action of ultraviolet-B radiation and cadmium on the growth of wheat seedlings. Ecotoxicol. Environ. Safety 51:90-96.

Singh A (1996) Growth, physiological and biochemical responses of three tropical legumes to enhanced UV-B radiation. Can. J. Bot. 74:135-139.

Somashekaraiah BV, Padmaja K, Prasad ARK (1992) Phytotoxicity of cadmium ions on germinating seedlings of mung bean (Phaseolus vulgaris): Involvement of lipid peroxides in chlorophyll degradation. Physiol. Plant. 85:85-89.

Stobart AK, Griffith WT, Bukhari IA, Sherwood RP (1985) The effect of Cd on the biosynthesis of chlorophyll in leaves of barley. Physiol. Plant. 63:293-298.

Tevini M, Iwanzik W, Thoma U (1981) Some effects of enhanced UV-B radiation on the growth and composition of plants. Planta 153:388-394.

Tevini M (2000) UV-B effects on plants. In: Agrawal SB, Agrawal M (eds), Environmental Pollution and Plant Responses, pp.83-97. Lewis Publishers, Boca Raton, U.S.A. 